\title{
The Impact and Consequences of Tax Revenues' Components on Economic Indicators: Evidence from Panel Groups Data
}

\author{
Taufik Abdul Hakim and Imbarine Bujang \\ Additional information is available at the end of the chapter
}

http://dx.doi.org/10.5772/48415

\section{Introduction}

Taxes are one of the major revenue for a country in where taxes are collected from citizens, companies, investors and so on to generate economy. There have several impacts of taxes due to economic growth whether it is positive or negative impacts. According to Bofah (2003), taxes refer to the revenue that is collected by the government to provide services and finance themselves. According to the theory of tax competition, the government will reduce the taxes on mobile asset through the occurrence of globalization due to rise in economic growth in a country. Change in tax rate also will give the different impact to an open economy. According to Bretschger (2010), he found negative impacts of corporate taxes on openness and total tax revenue to the economic growth in 12 OECD countries. He also mentioned on the tax competition theory that argues that, when tax rate of capital is reduced, it will cause the capital inflow to a country. This is because; the tax rate is one of the cost for capital holder (Bucovetsky, 1991 and Wilson, 1991). These two researches were found that private return on investment is influenced by the changes in capital taxes.

There are more than 20 studies which look for evidence on tax rates and economic growth in the United States and internationally. In all of the studies, it was concluded that reduction of all marginal rates by $5 \%$ and average tax rates by $2.5 \%$ leads to increase $0.2 \%$ to $0.3 \%$ of long-term growth. Christina and David (2007) conducted study of the impact of changes in the level of taxation on economic growth in which they investigated the effects of tax on GDP in United State in the post-World War II period. The study found that a tax increase by $1 \%$ leads to reduced $2 \%$ to $3 \%$ of GDP in United State.

However, some of the studies give opposite results in term of the negative relationship between tax and economic growth. According to Uhliga and Yanagawa (1999), increased 
capital income taxes will generate the economy. This is because, the capital income accrues for the old, in which increase on the capital income taxes will burden tax for the young and increase their saving, if the interest elasticity of saving is low. The other study by Glomm and Ravikumar (1998), found that when the government reduces the capital income taxes, it will reduce the spending on education and the long-run growth. In this case, the capital income taxes have positive correlation with the economic growth. Besides that, Gober and Burns (1997) have done a study about the relationship between tax structure and economic indicators for the OECD countries. From their finding, total tax revenue has negative relationship with two economic indicators that are saving and investment. However, according to them, personal income tax, corporate income tax, sales tax (consumption tax) and other taxes are highly significant, in which there is positive relationship with economic growth (GDP or GNP).

This study also involves another variable that affects the collection of tax revenue in a country. The variable is inflation rates. Usually, if the country faces the economic crisis, the government will try to recover the problem using monetary or fiscal policy. In fiscal policy, the government will use either taxes or government spending based on the problem. High inflation rate in a country will force the government to increase the tax of goods and services due to increased the price and stabilize the consumption also aggregate expenditure. With that, excise tax on some products may be affected with the change in inflation rate (Tanzi, 1989).

\section{Literature review}

The previous empirical studies found that most of the tax structures were highly significant and related with the economic growth in a country. One of the earlier studies done by Marsden (1983) mentioned that change in tax policy will affect the economic planning. According to Gober and Burns (1997), a countries economy may be affect differently due to any changes in each tax components. Based on their finding, excise taxes as percentage of Ireland's total revenue was four times the level in U.S. Change in economic growth depends on each of tax structures (Gold, 1991).Mahdavi (2008) suggest that the effect of rises in total tax revenue will reduce the growth in developing countries. Due to by the fiscal crisis in the past several decades, several developing countries had to revive its economy by changing the level of taxes. Two of the early studies by Hinrisch (1966) and Musgrave (1969) examined the relationship between the ratio of tax revenue to GDP (TAX/GDP) and found it was relatively low in the developing countries.

One of the studies that focus on African countries by Leuthold (1991) was examined the effect of (TAX/GDP) from 1973 to 1981 which used the OLS estimation method. From his study, the share of agriculture will affect the level of taxation and robust the relationship of total tax revenue into direct and indirect taxes. The level of taxes will give the different effect to growth and other indicators caused by the macroeconomic variables such as extent of corruption and adversely affected by the inflation rate in nine African countries over the period 1985-1996 (Ghura, 1998). Agbeyegbe (2004) used the same geographical sample, 
which are 22 countries in sub-Saharan Africa from 1980 to 1996. The study examined the effect of tax revenue on trade liberalization or "openness". He focused on three components in total tax revenue (taxes on income, international trade and goods and services tax) which are as ratio of GDP and found the weak relation among these three tax types.

The potential variable that will change the amount of tax revenue is change in inflation rate in a country. High inflation rate in a country will force the government to increase the taxes on goods and services by increasing the price and stabilizing the consumption and aggregate expenditure. With that, excise tax on some products may be affected with the change in inflation rate (Tanzi, 1989). A study by Mahdavi (2008) mentioned the effect of income, profit and capital gain tax due to change in inflation rate and investment plans. Based on his study, when the inflation rates increase, the household will protect their assets by substituting it with the assets that less domestic tax such as jewelleries.

\subsection{Effect on Foreign Direct Investment (FDI)}

The other variable that included in this research is to study the effects of taxes on FDI. Usually, the tax rate on capital is measured by stock of capital or capital flows that related to the FDI. One of the earliest studies by Hartman (1984) was a study on the relationship between FDI, after-tax rate of return by foreign investors and capital in United State. From his study, he suggested that the tax has a strong relationship with FDI. The tax regime in Mexico and United State has responded to the U.S's FDI. Two of the previous studies give the direction about the impact of taxes on FDI which are study by Scholes and Wolfson (1992) and Hines (1999). Based on Scholes and Wolfson (1992), tax will affect the decision of foreign investors to invest in a country caused by the changing in rates of return on assets. They argue that higher in tax will reduce the rates of return and discourage the FDI in-flow to a country. Hines (1999) found that FDI is sensitive with the tax, in which high tax rates can change the foreign investment rapidly. He concludes that reduction of only $10 \%$ on tax rates will increase more than $10 \%$ in FDI.

\section{Data and methodology}

This study is based on studies by Gober and Burns (1997), Mahdavi (2008) and Gordon and $\mathrm{Li}$ (2009). The dependent variables change in GDP, ratio of gross saving to GDP (SAVING/GDP) and foreign direct investment as ratio to GDP (FDI/GDP) to relate it with all the component of taxes (independent variables) since 1960 to 2009.

\subsection{Data on tax policy in low, middle, and high income countries}

Table 2 shows the percentage of several important components of tax revenue among the countries based on the different level of income. Based on the Table, rich or high income countries collect total tax revenue as ratio of GDP (TTX) more than two times compared with the poor or low income countries, in which the rich countries collect revenue of $27.60 \%$ of GDP and poor countries only collected $11.89 \%$. This is caused by the high per capita 


\begin{tabular}{|c|l|}
\hline Variable & Definition \\
\hline & \\
GDP & Gross Domestic Product annual percentage change. \\
FDI & Foreign Direct Investment (inflow) divided by GDP. \\
SAV & Gross Saving divided by GDP. \\
IPCT & Taxes on income, profit and capital gain divided by total tax revenue. \\
GST & Taxes on goods and services divided by total tax revenue. \\
ITT & Taxes on international trade divided by total tax revenue. \\
ET & Taxes on export divided by total tax revenue. \\
TTR & Total tax rate divided by total profit. \\
TTX & Total tax revenue divided by GDP. \\
INF & Inflation rate (consumer price index). \\
\hline
\end{tabular}

Table 1. Definition and sources of variables.

\begin{tabular}{|c|c|c|c|c|}
\hline Variable & \multicolumn{2}{|c|}{ GNI per capita (US\$) } & & \\
\hline & $\leq 975(\%)$ & $976-3855(\%)$ & $3856-11905(\%)$ & $\geq 11906(\%)$ \\
\hline TTX & 11.89 & 15.75 & 20.80 & 27.60 \\
\hline IPCT & 19.82 & 28.34 & 33.00 & 48.25 \\
\hline GST & 26.53 & 31.86 & 34.87 & 22.50 \\
\hline ITT & 18.78 & 18.21 & 7.79 & 1.89 \\
\hline ET & 4.91 & 2.70 & 3.06 & NA \\
\hline TTR & 49.08 & 40.56 & 51.26 & 41.39 \\
\hline SAV & 15.78 & 19.87 & 20.18 & 25.13 \\
\hline FDI & 2.31 & 3.54 & 2.94 & 3.97 \\
\hline INF & 15.18 & 15.90 & 22.98 & 7.30 \\
\hline
\end{tabular}

Notes: Authors' calculations based on available data between 1960 and 2009 from World Data Catalogue (World Bank, 2010). The ranges for GNI per capita follow the World Bank 2008 classification of low income, lower middle income, upper middle income and high income countries. Data within each cell are weighted averages. Tax revenue (\% of GDP) is weighted by GDP, inflation rate, and the other components of taxes are weighted by the total tax revenue of each country.

Table 2. Sources of government revenue (1960 - 2009). 
income and large amount of international companies in many rich countries that leads to high taxes on income, profit, and capital gain as fraction of total tax revenue (IPCT). Among the four different levels of income, taxes on goods and services (GST) is the main source of tax revenue for the low and middle income countries, in which $34.87 \%$ of total tax revenue was collected in upper middle income countries. Inflation rate $(22.98 \%)$ also states the highest in the country.

\subsection{Unit root test}

This co-integration test is to test for the existence of unit root for these variables. For this study, Augmented Dickey - Fuller (ADF) test is used to test for the non-stationary and the regression function is:

$$
\Delta \mathrm{X}_{\mathrm{t}}=\delta_{0}+\delta_{1}+\delta_{2} \mathrm{X}_{\mathrm{t}-1}+\mathrm{t}-\mathrm{i}+\mu_{\mathrm{t}}
$$

Where, $\mathrm{Xt}$ is the logarithm of the model for all variables at time $\mathrm{t}$. For the variable that symbol is $\Delta \mathrm{X} t-1$ means that the first differences with lags of $\mathrm{k}$. The coefficients of $\delta 0, \delta 1, \delta 2$ and $\alpha i$ are being estimated. Only taxes on export (ET) and taxes on income, profit and capital gain (IPCT) are stationary at first difference for while the other variables are stationary at level

\subsection{Variance Inflation Factors (VIF)}

This method can detect the multicollinearity problem in an ordinary least squares (OLS) regression that examines the value of variance in the model. Based on this method, the value of variance will increase due to collinearity. According to Wooldridge (2000), variance of the OLS can be shown as follows:

$$
\operatorname{VIF}(\mathrm{i})=1 /\left(1-R^{2}\right)
$$

The higher VIF, the greater of finding i insignificant that will detect the problem of multicollinearity. The lower values of VIF (less than 10) indicate that all the models were not suffered from multicollinearity problem.

\subsection{Breusch-Pagan-Godfrey test}

This test will estimate the variance of the residuals from the model. Compared to the other methods of testing heteroscedasticity, this method is least general and most powerful. It is also useful to test in this study because more than one independent variable is involved.

$$
\mu^{2}=\beta_{0}+\beta_{1} X_{1 i}+\beta_{2} X_{2 i}+\ldots+\beta_{\kappa} X_{\kappa} I
$$

This method relates the observation $\mathrm{R}^{2}$ and the value of chi-squared. If the result show observation $\mathrm{R}^{2}$ is significant with chi-squared value, the null hypothesis of no heteroscedasticity will be rejected. 


\subsection{Glejser test}

The absolute value of the residual will detect the problem of heteroscedasticity.

$$
\left|\hat{\mathrm{u}}_{\mathrm{i}}\right|=\beta_{0}+\beta_{1} X_{\mathrm{i}}+\mathrm{e}_{\mathrm{i}}
$$

The $\left|\hat{u}_{i}\right|$ represent the residual and $\beta_{1} X_{i}$ indicates the independent variables in the model of regression.

\subsection{Harvey-Godfrey test}

This method transforms the residual to log square (lnRESID $\left.{ }^{2}\right)$. The equation for Harvey test can be shown as follow:

$$
\ln \mu^{2}=\beta_{0}+\beta_{1} X_{1 i}+\beta_{2} X_{2 i}+\ldots+\beta_{\kappa} X_{\kappa} I
$$

The null hypothesis that states no heteroscedasticity will be rejected if the value of chisquared test is significant. Overall results of the three tests for heteroscedasticity was shown in Table 3 below:

$\mathrm{H}_{0}=$ There is no heteroscedasticity in the model regression.

$\mathrm{H}_{1}=$ There is a heteroscedasticity in the model regression.

\begin{tabular}{|l|c|l|l|l|c|}
\hline & GNI per capita (US\$) & \multicolumn{5}{|l|}{} \\
\cline { 2 - 5 } & All & $\leq 975$ & $\mathbf{9 7 6 - 3 8 5 5}$ & $\mathbf{3 8 5 6 - 1 1 9 0 5}$ & $\geq 11906$ \\
\hline Breusch-Pagan & Reject $\mathrm{H}_{0}$ & Reject $\mathrm{H}_{1}$ & Reject $\mathrm{H}_{0}$ & Reject $\mathrm{H}_{0}$ & Reject $\mathrm{H}_{1}$ \\
Harvey & Reject $\mathrm{H}_{0}$ & Reject $\mathrm{H}_{0}$ & Reject $\mathrm{H}_{1}$ & Reject $\mathrm{H}_{1}$ & Reject $\mathrm{H}_{1}$ \\
Glejser & Reject $\mathrm{H}_{0}$ & Reject $\mathrm{H}_{0}$ & Reject $\mathrm{H}_{1}$ & Reject $\mathrm{H}_{1}$ & Reject $\mathrm{H}_{1}$ \\
\hline
\end{tabular}

Table 3. Result of Heteroscedasticity test

Model regression for all 120 countries, low, lower and upper middle income countries rejected the null hypothesis that states no heteroscedasticity. It means that the model was strongly suffered from heteroscedasticity. However, heteroscedasticity was not found in the high income countries.

\section{Breusch-Godfrey Serial Correlation LM Test}

This method is used to detect the model regression for serial or autocorrelation problem. According to Gujarati and Porter (2010), this test is more general than several tests for autocorrelation. The residual regression is shown below:

$$
\mathrm{e}_{\mathrm{t}}=\beta_{1}+\beta_{2} \mathrm{X}_{1 \mathrm{t}}+\beta_{2} \mathrm{X}_{2 \mathrm{t}}+\mathrm{C}_{1} \mathrm{e}_{\mathrm{t}-1}+\mathrm{C}_{2} \mathrm{e}_{\mathrm{t}-2}+\ldots . .+\mathrm{C}_{k} \mathrm{e}_{\mathrm{t}-\mathrm{k}}+\mathrm{v}_{\mathrm{t}}
$$

The regression above also called by auxiliary regression that obtain the observation $R^{2}\left(o b s^{*} R^{2}\right)$ from the residuals regression $\left(n R^{2} \sim\right)$. If the value of $\mathrm{obs}^{*} \mathrm{R}^{2}$ are significant with the probability of chi-squared, the null hypothesis will be rejected. The result shows that, the model regression for 
high income countries is significant for this method. The value of $\mathrm{nR}^{2} \sim 13.57=$, in which the value of probability for chi-squared as much as 13.57 or greater for 5 d.f is significant at $5 \%$ level.

\section{Hypothesis}

\section{Hypothesis one}

For the first hypothesis, the dependent variable is annual change of GDP and the independent variables are the component of taxes as ratio to total tax revenue, total tax rate, and total tax revenue as ratio to GDP. The first hypothesis stated in null form is:

- Ho: There is no relationship between tax components and inflation rate on GDP for a given countries based on the level of income.

- H1: There is a relationship between tax components and inflation rate on GDP for a given countries based on the level of income.

All the variables were transformed to the log difference. Due to the problem of heteroscedasticity, models regression for all 120 countries, low, lower middle and upper middle income countries have to be transformed as the square root transformation. This remedial measure follows Gujarati and Porter (2010). According to them, the error variance $v_{i}=u_{i} /$ in the transformed regression is homoscedasticity. For high income countries, the model regression for error term $\mu_{\mathrm{t}}$ was transformed to one-period lag that multiply with the $\rho$ value was showed no serial correlation. The error term follow the AR (1) scheme:

$$
\mu_{\mathrm{t}}=\rho \mu_{\mathrm{t}-1}+v_{\mathrm{t}} \quad-1 \leq \rho \leq 1
$$

With that, the new equation for high income countries can be rewrite as:

$$
\left(Y_{t}-\rho Y_{t-1}\right)=\beta_{1}(1-\rho)+\beta_{2}\left(X_{t}-\rho X_{t-1}\right)+v_{t}
$$

The regression function for each models are:

All 120countries:

$$
\ln _{t}=\beta_{0 t}+\beta_{1} \ln _{t}+\beta_{2} \ln _{t}+\beta_{3} \ln _{t}+\beta_{4} \ln _{t}+\beta_{5} \ln _{t}+\beta_{6} \ln _{t}+\beta_{7} \ln _{t}+\mu_{t}
$$

High income countries:

$$
\begin{gathered}
\Delta \ln \rho G D P P_{\mathrm{t}-1}=\beta_{0}(1-\rho)_{\mathrm{t}}+\beta_{1} \Delta \ln \rho T_{T X} X_{\mathrm{t}-1}+\beta_{2} \Delta \ln \mathrm{ln}_{\mathrm{tPCT}} \mathrm{IPC}_{\mathrm{t}-1}+\beta_{3} \Delta \ln \rho \mathrm{GST}_{\mathrm{t}-1}+\beta_{4} \Delta \ln \rho \mathrm{ET}_{\mathrm{t}-1}+\beta_{5} \Delta \ln \rho \mathrm{ITT}_{\mathrm{t}-} \\
1+\beta_{6} \Delta \ln \rho \mathrm{TTR}_{\mathrm{t}-1}+\beta_{7} \Delta \ln \rho \mathrm{INF}_{\mathrm{t}-1}+\mu_{\mathrm{t}}
\end{gathered}
$$

Lag one or two years and first or second difference for all variables are based on the stationary (unit root) test, means that value for each tax structures for the previous year(s) will affect the GDP for current year.

Hypothesis two

Hypothesis two estimates the ratio of gross saving to GDP as dependent variable due to the ratio of each components of tax revenue to total tax revenue and inflation rate. The null hypothesis is: 
- Ho: There is no relationship between tax components and inflation rate on saving for a given countries based on the level of income.

- H1: There is a relationship between tax components and inflation rate on saving for a given countries based on the level of income.

Change of the tax components such as goods and services tax, consumption tax, personal and income tax will also affect the gross saving in a country. It's based on the previous study by Gober and Burns (1997) that study about the relationship between tax structure and economic indicators using the cross sectional data of OECD's countries. However, the affect is not constant with the different level of income for the countries.

\section{Hypothesis three}

For this third hypothesis, the dependent variable is foreign direct investment (FDI) as ratio to GDP and the independent variables are the components of tax revenue as ratio to total tax revenue and inflation rate. The null hypothesis form is:

- H0: There is no relationship between tax components and inflation rate on FDI for a given countries based on the level of income.

- H1: There is a relationship between tax components and inflation rate on FDI for a given countries based on the level of income.

Based on the previous studies, inflow of FDI also is influenced by the change for each components of tax revenue in a country. Usually, the return that the investors will get is earning per share (EPS) or dividend per share (DPS) by the company. The investors will be attracted by higher EPS or DPS, in which both of this returns are influenced by inflation rate and tax rates. The formula of EPS can be shown as:

$$
\text { EPS }=
$$

With that equation, increase in rates of corporate income tax and taxes on profit will reduce the EPS and discourage investors to invest.

\section{Findings}

The square root transformation of ordinary least squared (OLS) is used to estimate the unknown parameters in regression model for the three hypotheses.

\subsection{All countries}

The null hypothesis states that there is no relationship between components of tax revenue and inflation rate on GDP, inflow of FDI, and gross saving for a given countries based on the level of income, is rejected. Based on the Table 4, the regression shows that there is a relationship between the ratios of components of tax revenue to total tax revenue and inflation rate on economic indicators. The null hypothesis is rejected based on the significant (0.1, 0.05 or 0.01 level), using P-value in OLS method. 


\begin{tabular}{|lccc|}
\hline & $(1)$ & $(2)$ & $(3)$ \\
& $\Delta \ln (\mathrm{GDP} /())$ & $\Delta \ln (\mathrm{SAV} /())$ & $\Delta \ln (\mathrm{FDI} /())$ \\
\hline $\ln (\mathrm{ET} /())$ & 0.052732 & 0.106424 & -0.028067 \\
& $(0.048729)$ & $(0.151287)$ & $(0.039931)$ \\
$\ln (\mathrm{GST} /())$ & $0.140677^{* * *}$ & $0.329904^{* * *}$ & $0.044219^{*}$ \\
& $(0.024231)$ & $(0.075228)$ & $(0.025958)$ \\
$\ln (\mathrm{INF} /())$ & $-0.050570^{* *}$ & -0.018236 & $0.034902^{* *}$ \\
& $(0.021850)$ & $(0.067836)$ & $(0.015281)$ \\
$\ln (\mathrm{IPCT} /())$ & $0.272917^{* * *}$ & $0.443273^{* * *}$ & -0.000393 \\
& $(0.025914)$ & $(0.080453)$ & $(0.026812)$ \\
$\ln ((\mathrm{ITT} /())$ & $0.216337^{* * *}$ & $0.408508^{* * *}$ & -0.014601 \\
& $(0.026501)$ & $(0.082275)$ & $(0.027654)$ \\
$\ln ()$ & $0.449083^{* * *}$ & $-0.987863^{* *}$ & -0.113624 \\
& $(0.156441)$ & $(0.485694)$ & $(0.133659)$ \\
$\ln ((\mathrm{TTR} /())$ & $0.089823^{* * *}$ & 0.050482 & -0.021454 \\
& $(0.016281)$ & $(0.050548)$ & $(0.013351)$ \\
$(1 /())$ & $-0.553458^{* * *}$ & 0.093488 & $0.105316^{*}$ \\
& $(0.074562)$ & $(0.231488)$ & $(0.052510$ \\
& & & \\
R-squared & 0.992899 & 0.970843 & 0.257284 \\
Adjusted R-squared 0.992455 & 0.969021 & 0.162064 \\
F-statistic & 2237.176 & 532.7575 & 2.701999 \\
No. observations & 120 & 12 & 120 \\
\hline
\end{tabular}

Notes: Values in parentheses are standard error. ${ }^{* * *},{ }^{* *}$, and ${ }^{*}$ indicates significant at $0.01,0.05$, and 0.1 level.

Table 4. All countries

Column (1), (2), and (3) on the top of table represents the results for the three hypothesis based on the different three dependent variables (GDP, gross saving, and FDI-inflow). Total tax revenue (TTX) as ratio to GDP is highly significant with the two economic indicators, in which showed the negative relation to saving and FDI. These results are same results that found by Gober and Burns (1997), Marsden (1983) and Smith (1990). Surprisingly, total tax revenue has high positive significance to the change in GDP, in which four of the components of tax revenue (GST, IPCT, ITT, and TTR) showed the high positive and significance. However, the impacts of tax revenue on the three indicators are not consistent for all countries in the four level of income. The high $\mathrm{R}^{2}$ for model (1) and (2) showed that the independent variables are highly correlated with the dependent variables.

The other potential variable that is involved in this study is inflation rate, in which indicates the negative sign to the GDP and gross saving, while showing significant positive effect to the FDI. This result suggests that inflation rate will affect directly to plans of FDI by increasing in inflation rate in a country will increase the taxes and generate the inflow of FDI in a country. This is based on Mahdavi (2008) that found increase in inflation rate will increase the tax revenue through the increase in sales tax. Additionally, the study by Scholes and Wolfson (1992) suggest, an increase in tax will also increase the FDI-inflow. 


\subsection{Low income countries}

Only 11 percent of GDP contributed to the revenue each country in this level of income. Taxes on goods and services have the highest percentage among all components of tax, in which 27 percent are from total tax revenue.

\begin{tabular}{|lccc|}
\hline & $(1)$ & $(2)$ & $(3)$ \\
$\Delta \ln (\mathrm{GDP} /())$ & $\Delta^{2} \ln (\mathrm{SAV} /())$ & $\Delta^{2} \ln (\mathrm{FDI} /())$ & 0.071701 \\
$\Delta \Delta^{2} \ln (\mathrm{ET} /())$ & $0.004116^{*}$ & $0.140740^{* *}$ & $(0.079145)$ \\
& $(0.002206)$ & $(0.051837)$ & $2.828571^{* *}$ \\
$\Delta \ln (\mathrm{GST} /())$ & $0.083729^{* *}$ & 1.108370 & $(1.220902)$ \\
& $(0.033901)$ & $(0.901270)$ & $0.452805^{* *}$ \\
$\Delta^{2} \ln (\mathrm{INF} /())$ & -0.006402 & $-0.340943^{*}$ & $(0.174043)$ \\
& $(0.007656)$ & $(0.183899)$ & 0.213314 \\
$\Delta^{2} \ln (\mathrm{IPCT} /())$ & $0.025607^{* *}$ & $0.710050^{* *}$ & $(0.478474)$ \\
& $(0.012414)$ & $(0.307536)$ & $0.710989^{*}$ \\
$\Delta^{2} \ln (\mathrm{ITT} /())$ & -0.010491 & $-0.523789^{* *}$ & $(0.372067)$ \\
& $(0.014244)$ & $(0.245165)$ & $-2.436644^{* *}$ \\
$\Delta \ln ()$ & $0.086472^{* * *}$ & $0.973560^{* *}$ & $(0.966585)$ \\
$\Delta \ln (\mathrm{TTX} /())$ & $(0.025902)$ & $(0.451495)$ & $-4.719960^{*}$ \\
& $-0.075491^{* *}$ & $-0.502112^{* * *}$ & $(2.280927)$ \\
$(1 /())$ & $(0.028567)$ & $(0.165618)$ & $2.099512^{* *}$ \\
& $0.086768^{* *}$ & -1.364480 & $(0.333206)$ \\
& $(0.036923)$ & $(0.915260)$ & \\
R-squared & & & 0.632356 \\
Adjusted R-squared 0.606580 & 0.391606 & 0.356624 \\
F-statistic & 4.924613 & 2.386369 & 2.293367 \\
No. observations & 30 & 30 & 30 \\
\hline
\end{tabular}

Notes: Values in parentheses are standard error. ${ }^{* * *},{ }^{* *}$, and * indicates significant at $0.01,0.05$, and 0.1 level.

Table 5. Low income countries

Based on Table 5, GST was positively significant to the GDP and FDI. This study found that increase in GST will generate the growth and inflow of FDI in a country. TTR also has the significant effect to the three indicators, has positive effect to GDP and SAV, but negative relationship with the inflow of FDI. This result show that rates of tax is the cost in investment, in which increase in rates of tax will increase the cost of investment and discourage investors to invest in a company. The SAV and FDI have highly significant with the taxes on international trade (ITT) on the second difference and lagged two years. However ITT does not have the same effect on both of the economic indicators, in which negative effect on gross saving but positive effect on FDI. Increase in ITT will increase the price of imported goods and relatively price of domestic goods are cheaper than imported 
good. This situation will lowers the taxes on domestic goods and services which are encourage consumption on domestic goods and reduce gross saving.

\subsection{Lower middle income countries}

All four components of tax revenue (ET, IPCT, ITT, and ET) were contributed 81 percent of total tax revenue. With that, the TTX was directly affected by these components of tax revenue and affect the three economic indicators.

\begin{tabular}{|lccc|}
\hline & $(1)$ & $(2)$ & $(3)$ \\
& $\Delta \ln (\mathrm{GDP} /())$ & $\Delta \ln (\mathrm{SAV} /())$ & $\Delta \ln (\mathrm{FDI} /())$ \\
\hline$\Delta \ln ()$ & $0.127092^{* * *}$ & $0.101162^{* * *}$ & $0.041029^{* * *}$ \\
$\Delta \ln (\mathrm{GST} /())$ & $(0.019778)$ & $(0.003365)$ & $(0.000300)$ \\
& $-0.126540^{* * *}$ & -0.199845 & -0.009767 \\
$\Delta^{2} \ln (\mathrm{INF} /())$ & $(0.041591)$ & $(0.254834)$ & $(0.034629)$ \\
& -0.029079 & $0.977954^{* * *}$ & $-0.113493^{* *}$ \\
$\Delta^{2} \ln (\mathrm{IPCT} /())$ & $(0.051961)$ & $(0.319115)$ & $(0.043264)$ \\
& -0.024651 & $0.793698^{* *}$ & $0.095368^{*}$ \\
$\Delta^{2} \ln (\mathrm{ITT} /())$ & $(0.086117)$ & $(0.313223)$ & $(0.050239)$ \\
& $-0.152141^{* *}$ & $-0.635001^{*}$ & $-0.126333^{* * *}$ \\
$\Delta \ln (\mathrm{TTX} /())$ & $(0.070476)$ & $(0.296184)$ & $(0.032095)$ \\
& $-0.295484^{* * *}$ & $-1.081111^{* *}$ & -0.058318 \\
$\Delta^{2} \ln (\mathrm{TTR} /())$ & $(0.091906)$ & $(0.419215)$ & $(0.076522)$ \\
& 0.038275 & -1.174050 & $-0.104859^{*}$ \\
$(1 /()$ & $(0.052312)$ & $(1.038849)$ & $(0.045704)$ \\
& $-0.093347^{* *}$ & 0.527982 & $-0.181886^{* * *}$ \\
& $(0.048015)$ & $(0.437581)$ & $(0.046372)$ \\
& & & \\
R-squared & 0.999739 & 0.991386 & 0.999692 \\
Adjusted R-squared 0.999477 & 0.988213 & 0.999384 \\
F-statistic & 3823.683 & 312.3938 & 3246.214 \\
No. observations & 30 & 30 & 30 \\
\hline
\end{tabular}

Notes: Values in parentheses are standard error. ${ }^{* * *},{ }^{* *}$, and ${ }^{*}$ indicates significant at $0.01,0.05$, and 0.1 level.

Table 6. Lower income countries

Table 6 examined the parameters of the equation for components of tax revenue in the lower middle income countries. Based on the Table, total tax revenue on the first difference has negative effect to the growth of GDP, in which reduce 0.30 percent for each 1 percent increase in TTX. The same effect also shows on the other two indicators. The ET in this group of countries is the lowest percentage among the other group of countries. That component of tax was highly significant and had positive effect to the GDP, SAV, and FDI, in which will generate the economic from 0.04 to 0.13 percent. 
The most affected on the three indicators by IPCT was on gross saving to GDP-ratio that increase 1 point in IPCT will increase 0.79 percent to SAV. Gross saving was affected most by ITT, in which discourage 0.64 percent in SAV. The result was influenced by the consumption on domestic goods and services. Increase in ITT will increase the price of imported goods and is relatively expensive than domestic goods. This situation increased consumption of domestic goods while reduced the domestic saving in a country.

\subsection{Upper middle income countries}

The percentage of total tax revenue of GDP is more than 20 percent in this group. It means, the tax revenue was higher in the higher income countries. However, the inflation rate is the highest in this group (23\%) compared with the other groups of countries. The expectation of this study that relate inflation rate and taxes by goods and services tax can be shown by higher in inflation rate which will generate more to GST. The taxes on goods and services have 35 percent of total tax revenue that contributed the highest percentage in this group. Table 7 shows the coefficient of parameter for each of the variables.

\begin{tabular}{|lccc|}
\hline & $(1)$ & $(3)$ & \\
& $\Delta \ln (\mathrm{GDP} /())$ & $\Delta \ln (\mathrm{SAV} /())$ & $\Delta^{2} \ln (\mathrm{FDI} /())$ \\
\hline$\Delta \ln (\mathrm{ET} /())$ & 0.080414 & -0.005814 & 0.965147 \\
& $(0.315284)$ & $(0.619843)$ & $(5.111205)$ \\
$\Delta \ln (\mathrm{GST} /())$ & -0.111859 & $-0.261029^{* * *}$ & $-3.972020^{* *}$ \\
& $(0.184919)$ & $(0.036354)$ & $(1.223192)$ \\
$\Delta \ln (\mathrm{INF} /())$ & $-0.103090^{* *}$ & -0.013045 & 0.277478 \\
& $(0.047930)$ & $(0.094230)$ & $(0.788610)$ \\
$\Delta \ln ()$ & $0.340124^{* *}$ & $0.097691^{* * *}$ & 0.937624 \\
& $(0.102388)$ & $(0.020129)$ & $(1.656401)$ \\
$\Delta \ln ((\mathrm{ITT} /())$ & 0.144577 & $0.613801^{* *}$ & $-2.459903^{* *}$ \\
& $(0.121094)$ & $(0.238068)$ & $(1.114730)$ \\
$\Delta \ln ()$ & $-0.082579^{*}$ & $0.070147^{* *}$ & -0.115269 \\
& $(0.038906)$ & $(0.033425)$ & $(0.645417)$ \\
$\Delta \ln (\mathrm{TTX} /())$ & $-0.241508^{*}$ & -0.096494 & 3.329078 \\
& $(0.135578)$ & $(0.444352)$ & $(3.938132)$ \\
$\Delta 2 \ln (\mathrm{TTX} /())$ & -0.015812 & 0.014138 & $-1.425103^{*}$ \\
& $(0.038992)$ & $(0.076659)$ & $(0.720536)$ \\
$(1 /)$ & $-0.315512^{* * *}$ & $0.234584^{*}$ & $0.350857^{* *}$ \\
& $(0.058128)$ & $(0.114279)$ & $(0.239737)$ \\
R-squared & 0.876603 & 0.565446 & 0.649214 \\
Adjusted R-squared 0.784056 & 0.239531 & 0.348540 \\
F-statistic & 9.471929 & 9.441269 & 7.844066 \\
No. observations & 30 & 30 & 30 \\
\hline
\end{tabular}

Notes: Values in parentheses are standard error. ${ }^{* * *},{ }^{* *}$, and * indicates significant at $0.01,0.05$, and 0.1 level.

Table 7. Upper middle income countries 
The taxes on goods and services (GST) that contributed the highest percentage of total tax revenue had negative and highly significant to the dependent variables. This result is not consistent with the low income countries, in which it had positive effect to the economic growth. From the findings, this study concludes the different effects of the tax components based on the different tax structures and different tax policy for each group of countries. The rates of inflation also influence these tax components. The second highest percentage of tax revenue is taxes on income, profit, and capital gain (IPCT) also shows the significant coefficient to the economic indicators. The parameter of coefficient of IPCT has positive correlation on GDP, gross saving, and inflow of FDI in a country. The significance of this variable indicates that IPCT as revenue to an upper middle or developing countries that will contribute to generate economy. Based on this study, high level of income in the countries will increase the IPCT.

\subsection{High income countries}

This level of countries has the highest income per capita. These countries also called as rich or developed countries. Total tax revenue in this group of countries contributed 28 percent of GDP, in which the highest component of tax revenue was taxes on income, profit and capital gain (IPCT). This group has the lowest inflation rate (7\%) and the lowest percentage of GST among the groups of country. Based on these results, this study suggest that inflation rate affected the tax revenue on GST and the higher income per capita in a country will contribute higher IPCT.

\begin{tabular}{|lccc|}
\hline & $(1)$ & $(2)$ & $(3)$ \\
& $\Delta \ln \rho$ GDP & $\Delta \ln \rho$ SAV & $\Delta \ln \rho$ FDI \\
\hline$\Delta \ln \rho$ GST & -0.000547 & $-0.440172^{* *}$ & $0.188973^{*}$ \\
& $(0.042312)$ & $(0.182018)$ & $(0.106621)$ \\
$\Delta \ln \rho$ INF & -0.020855 & -0.098160 & -0.074966 \\
& $(0.035559)$ & $(0.152969)$ & $(0.089605)$ \\
$\Delta \ln \rho$ IPCT & $0.060493^{* * *}$ & $-0.236123^{* * *}$ & $0.088073^{* *}$ \\
& $(0.015169)$ & $(0.065255)$ & $(0.038224)$ \\
$\Delta \ln \rho$ ITT & 0.056751 & $-1.542499^{*}$ & $0.670518^{*}$ \\
& $(0.200967)$ & $(0.806938)$ & $(0.363431)$ \\
$\Delta \ln \rho$ TTR & $-0.072165^{* *}$ & $-0.278812^{*}$ & -0.016070 \\
& $(0.034403)$ & $(0.147994)$ & $(0.086691)$ \\
$\Delta \rho \ln T T X$ & $0.033375^{* * *}$ & $0.481297^{* * *}$ & $-0.043469^{*}$ \\
& $(0.008764)$ & $(0.037702)$ & $(0.019591)$ \\
1 - $\rho$ & 0.003555 & $0.087138^{*}$ & -0.015224 \\
& $(0.011677)$ & $(0.047841)$ & $(0.016530)$ \\
R-squared & 0.853691 & 0.937180 & 0.329289 \\
Adjusted R-squared 0.815523 & 0.920793 & 0.154321 \\
F-statistic & 22.36688 & 57.18804 & 2.763909 \\
No. observations & 30 & 30 & 30 \\
\hline
\end{tabular}

Notes: Values in parentheses are standard error. ${ }^{* * *}, * *$, and ${ }^{*}$ indicates significant at $0.01,0.05$, and 0.1 level.

Table 8. High income countries 


\begin{tabular}{|c|c|c|c|}
\hline $\begin{array}{c}\text { Dependent } \\
\text { Variable }\end{array}$ & Hypothesis tested & F1 & F2 \\
\hline $\operatorname{lnGDP}$ & 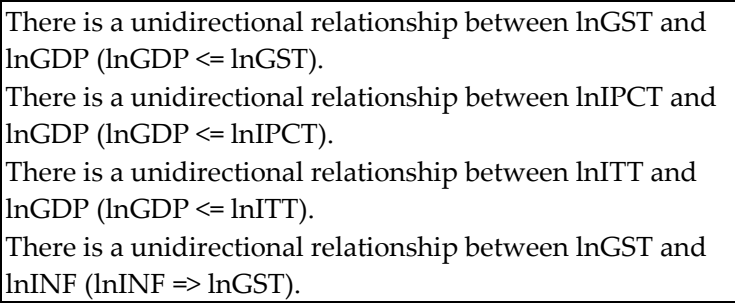 & $\begin{array}{l}4.93467^{* * *} \\
5.10761^{* * *} \\
14.1273^{* * *} \\
1.82627\end{array}$ & $\begin{array}{l}0.99348 \\
0.77747 \\
1.29654 \\
5.72733^{* * *}\end{array}$ \\
\hline $\operatorname{lnSAV}$ & 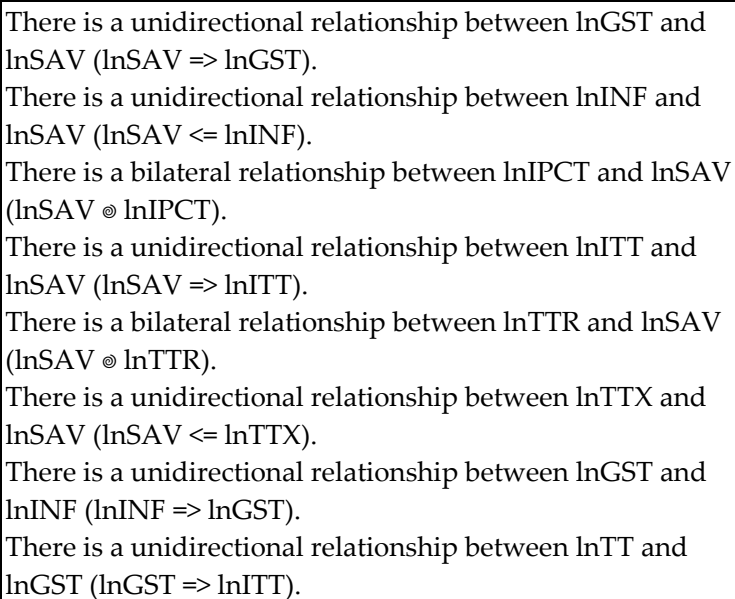 & $\begin{array}{l}0.26215 \\
2.35779^{*} \\
6.21313^{* * *} \\
1.14057 \\
4.87729^{* * *} \\
3.26684^{* *} \\
2.00220 \\
2.02530\end{array}$ & $\begin{array}{l}2.39471^{*} \\
1.28879 \\
2.44256^{*} \\
3.41127^{* *} \\
2.27390^{*} \\
1.57568 \\
2.14039^{*} \\
2.46395^{*}\end{array}$ \\
\hline $\operatorname{lnFDI}$ & 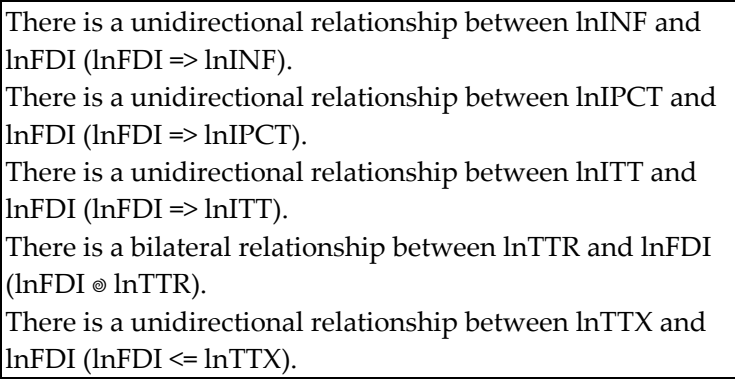 & $\begin{array}{l}1.21026 \\
0.60109 \\
0.25346 \\
4.48555^{* *} \\
4.42107^{* *}\end{array}$ & $\begin{array}{l}4.26882^{* *} \\
7.20832^{* * *} \\
3.07362^{*} \\
10.2675^{* * *} \\
0.15690\end{array}$ \\
\hline
\end{tabular}

Notes: ${ }^{* * *},{ }^{* *}$, and ${ }^{*}$ indicates significant at $0.01,0.05$, and 0.1 level.

Table 9. Granger causality tests

The parameter of coefficient for high income countries was shown in Table 8. Based on the Table, the coefficient for TTX shows the significant and different affect to all three economic indicators. Opposite result in TTX on the economic growth, in which TTX will generate the GDP compared with the low and middle income countries. This result was influenced by the different tax policy and lower inflation rate in a rich country. This is based on the study by Mahdavi (2008) that mentioned inflation rate is one of the potential variables that will influence the tax revenue and tax policy in a country. Increase in tax and tax policy was dramatically used by the low and middle income countries due to reducing the high 
inflation. With that, the effect of TTX on economic growth for the three levels of countries showed negative impact caused by TTX is generated by tax policy and forced the tax such as taxes on goods and services (GST) to increase. However, in high income countries that has low inflation rate, the countries did not increase the tax and tax policy dramatically, while the most important and highest percentage of tax revenue on high income countries was generated by taxes on income, profit, and capital gain. High in tax revenue was not forced by high inflation rate, but generated by high in per capita income and revenue or profit in many medium sized and large companies in a high income country.

\section{Further analysis using Granger causality test}

In order to test whether the time series data has causal relationship between all the variables, this study uses the Granger causality test. This test was also used by the previous study such as Anastassiou and Dritsaki (2005) by referring to the F statistic. Each of the variables is separate in function, in which the hypothesis of statistical significance for the $F$ statistic in a group of variables to examine the relationship. The result shows that the independent variables have Granger causal relationship to the dependent variables. Table 9 shows the Granger causality test for all the variables that involves all 120 countries.

Based on Table 9, almost all the components of tax revenue in 120 countries, in which it involved four groups of country, have causal relationship with the annual change in GDP, gross saving to GDP-ratio, and FDI-inflow to GDP-ratio. It is based on the value of F-test that significant at $0.01,0.05$, and 0.01 levels. This results shows that the components of tax revenue that involve in this study were significant to relate it with the economic growth and other economic indicators. The potential variable, inflation rate also has causal relationship with the taxes such as GST. With that, it proves the inflation rate in a country will affect the GST to change. For the FDI-inflow, we can conclude that total tax rate (TTR) and FDI correlated with each other based on this method. The result supports the study of investment and tax rate by Palacios and Harischandra (2008) that mentioned, an investor's willing to invest is higher if the marginal tax rates are lower by increasing the returns on investment.

\section{Conclusions}

From the regression analysis, the main findings may be summarized as follows:

1. This study found statistical evidence suggesting that the total tax revenue to GDP ratio is higher in the high income countries compared with the low and middle countries.

2. The inflation rate in a country was significant and directly affect the components of tax revenue especially taxes on goods and services (GST). The higher inflation rate in low and middle income countries has the highest percentage of GST to total tax revenue ratio.

3. Taxes on income, profit, and capital gain (IPCT) will contribute more on total tax revenue in the higher income countries. Increase in IPCT was generated by increase in per capita income and many medium sized and large companies that has higher profit 
to be taxed by the government in a country. Total tax rate (TTR) was highly significant on the FDI-inflow, in which corporate tax rate and marginal tax rate as the cost to investment. This result suggests that increase in TTR will reduce both profit of a company and rate of returns on investment (FDI).

4. Increase in total tax revenue (TTX) will encourage gross saving to increase in a country caused by increase in GST or sales tax that reduces consumption. However, taxes on international trade (ITT) has negative impact to gross saving, in which increase in ITT will increase the price of imported goods and relatively expensive than domestic goods that will encourage consumption and reduce gross saving.

Inconsistent impacts of TTX and the other components of tax revenue that involve in this study caused by the different levels of income in a country. Besides, the potential variable such as inflation rate will affect the tax reformed and tax policy that give different impacts to the economic growth, gross saving to GDP ratio and FDI-inflow to GDP ratio.

\section{Author details}

Taufik Abdul Hakim and Imbarine Bujang

Faculty of Business Management, Universiti Teknologi MARA, Sabah Malaysia

\section{Appendix}

\begin{tabular}{|l|l|l|l|}
\hline Low income & Lower middle income & Upper middle income & High income \\
\hline Afghanistan & Angola & Algeria & Andorra \\
Bangladesh & Belize & Argentina & Australia \\
Benin & Bolivia & Belarus & Bahrain \\
Cambodia & Cameroon & Bosnia and Herzegovina & Belgium \\
Comoros & China & Brazil & Brunei \\
Congo Dem Rep & Cote d'Ivoire & Bulgaria & Canada \\
Eritrea & Ecuador & Chile & Croatia \\
Ethiopia & Georgia & Colombia & Czech Republic \\
Ghana & Guyana & Costa Rica & Denmark \\
Guinea & Honduras & Cuba & Finland \\
Haiti & India & Dominica & France \\
Kenya & Indonesia & Fermany \\
Liberia & Iraq & Gabon \\
Malawi & Jordan & Greece \\
Mali & Kosovo & Jamaica & Kong Kong China \\
Mauritania & Maldives & Kazakhstan \\
Mozambique & Moldova & Latvia \\
Myanmar & Mongolia & Malaysia \\
Nepal & Paraguay & Mexico & Japan \\
Niger & Philippines & Kamibia & Kalau \\
\hline
\end{tabular}




\begin{tabular}{|l|l|l|l|}
\hline Rwanda & Samoa & Panama & Oman \\
Senegal & Sri Lanka & Peru & Portugal \\
Somalia & Sudan & Poland & Singapore \\
Tajikistan & Swaziland & Romania & Spain \\
Tanzania & Thailand & Serbia & Sweden \\
Togo & Timor-Leste & South Africa & Switzerland \\
Uganda & Tonga & Suriname & Trinidad and Tobago \\
Uzbekistan & Tunisia & Turkey & United Arab Emirates \\
Vietnam & Ukraine & Uruguay & United Kingdom \\
Zimbabwe & Vanuatu & Venezuela RB & United State \\
\hline
\end{tabular}

Table 10. Countries in the sample.

\section{References}

[1] Agbeyegbe, Terence, Stotsky J. G., and WoldeMariam A., (2004). Trade liberalization, exchange rate changes, and tax revenue in sub-Saharan Africa. IMF Working Paper WP/04/178 Washington D.C.: International Monetary Fund .

[2] Anastassiou T., and Dritsaki C., (2005). Tax Revenues and Economic Growth: An Empirical Investigation for Greece Using Causality Analysis. Journal of Social Sciences, 1, 99-104.

[3] Bofah K., (2003). The Impact of Tax on Investment and Business Decisions. htttp://www.ehow.com/facts_5910416_impact-tax-investment-business-decisions.html

[4] Bretschger L., (2010). Taxes, mobile capital, and economic dynamics in a globalizing world. Journal of Macroeconomics 32, 594-605.

[5] Bucovetsky S., (1991). Asymmetric tax competition. Journal of Urban Economics 30, 167181.

[6] Christina and David R., (2007). The Macroeconomic Effects of Tax Changes: Estimates Based on New Measure of Fiscal Shocks, NBER Working Paper 13264

[7] Ghura H.,. (1998). Tax revenue in sub-Saharan Africa: Effects of economic policies and corruption. WP/98/135 Washington D.C.: International Monetary Fund .

[8] Glomm G., and Ravikumar B., ( 1998). Taxes government spending on education and growth. Review of Economic Dynamics 1, 306-325.

[9] Gober J.R., and Burns J.O., (1997). The Relationship Between Tax Structures and Economic Indicators. Journal of International Accounting, Auditing \& Taxation, 6, 1-24.

[10] Gold S.D., (1991). Changes in state government finances in the 1980s. National Tax Journal 44, 1-19.

[11] Gordon R., and Li W., (2009). Tax structures in developing countries: Many puzzles and a possible explanation. Journal of Public Economics 93, 855-866.

[12] Gujarati D.M., and Porter D.C., (2010). Essential of Econometrics. New York: McGraw Hill.

[13] Hartman, D. G., (1984). Tax policy and foreign direct investment. Journal of Public Economics 26, 107-121. 
[14] Hines J.R., (1999). Taxes and the location of foreign direct investment in America. American Economic Review 86, 1076-1094.

[15] Hinrisch H.H., (1966). A general theory of tax structure change during economic development. Harvard Law School International Tax Program Development .

[16] Leuthold J. H., (1991). Tax shares in developing economies: A panel study. Journal of Development Economics, 35, 173-185.

[17] Mahdavi S., (2008). The level and composition of tax revenue in developing countries:Evidence from unbalanced panel data. International Review of Economics and Finance 17, 607-617.

[18] Marsden K., (1983). Links between taxes and economic growth. World Bank Staff Working Paper Number 605, The World Bank, Washington, D.C.

[19] Musgrave R. A., (1969). Fiscal systems. : Yale University Press.

[20] Palacios M., and Harischandra K., (2008). The impact of taxes on economic behavior, NBER Working Paper 13264.

[21] Scholes M.S., and Wolfson M.A., (1992). Taxes and business strategy: A planning approach. Prentice-Hall, Englewood Cliffs, NJ .

[22] Smith R., (1990). Factors affecting saving, policy tools, and tax reform. International Monetory Fund Stuff Papers 37, 1-70.

[23] Tanzi V., (1989). The impact of macroeconomic policies on the level of taxation and the fiscal balance. International Monetary Fund Stuff Papers 36, 633-656.

[24] Uhliga H., and Yanagawa N., (1999). Increasing the capital income tax may lead to faster growth. European Economic Review, 40, 1521-1540 .

[25] Wilson J.D., (1991). Tax competition with interregional differences in factor endowments. Regional Science and Urban Economics 21, 423-451.

[26] Wooldridge J. M., (2000). Introductory Econometrics: A Modern Approach. South Western.

[27] World Bank. (2010). World Development Indicators. World Bank, Washington, D.C. 